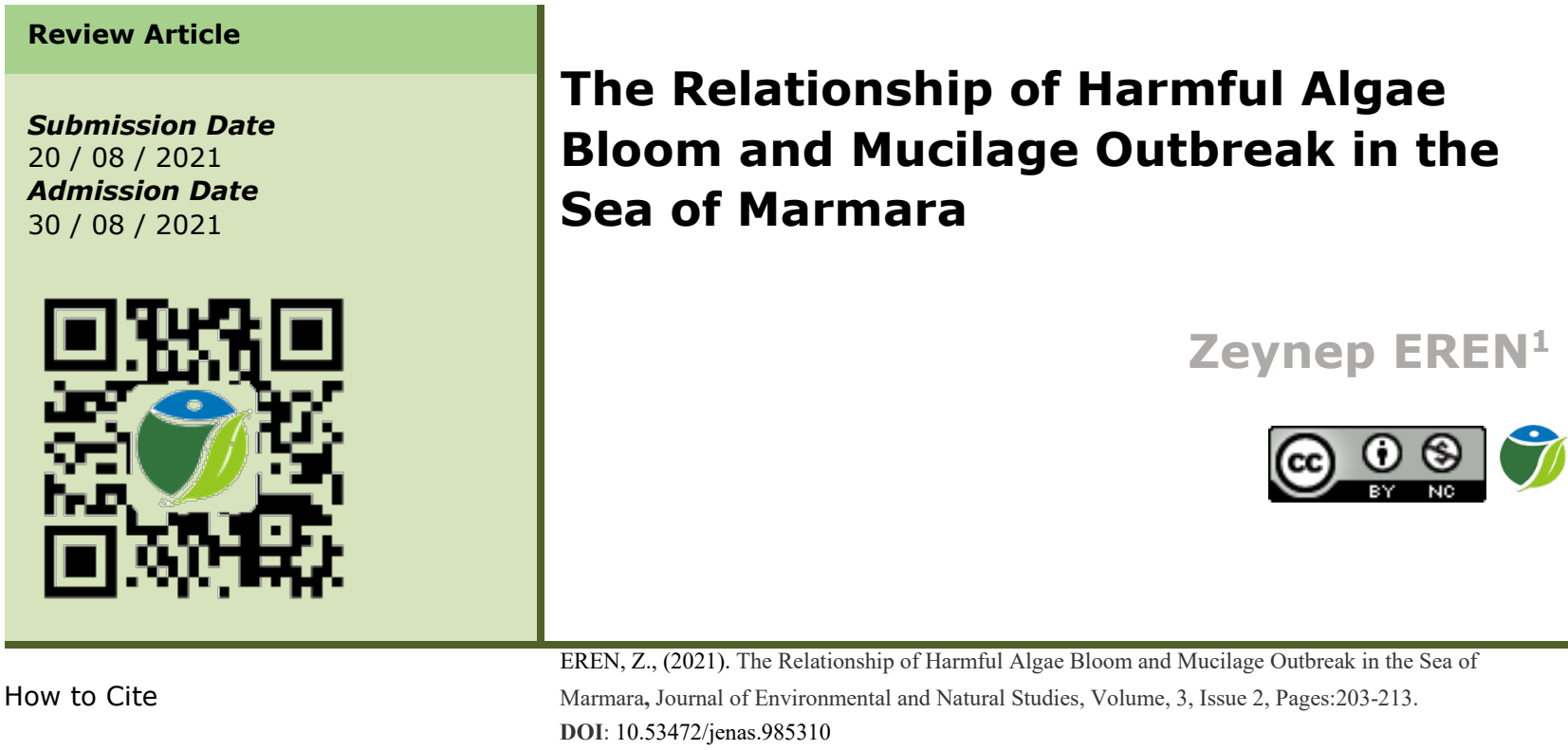

\title{
Zararlı Alg Patlaması ve Marmara Denizindeki Müsilaj Problemi İlişkisi
}

\begin{abstract}
:
Harmful phytoplankton species become dominant by increasing with the change of trophic conditions in aquatic environments that are under the pressure of many environmental problems such as pollution, overfishing, invasive species, and climate change. The overgrowth of these harmful phytoplankton species is often referred to as harmful algae growth or algal bloom, and as a result; a high amount of extracellular polymeric organic matter is secreted from the large number of living cells newly formed. These extracellular organic substances called mucilage; it is mostly produced by diatoms and dinoflagellates. This article provides basic information for describing the phytoplankton and the understanding of eutrophication and the mucilage problem caused by phytoplankton.
\end{abstract}

KEYWORDS: Phytoplankton, Harmful algae, Eutrophication, Mucilage.

ÖZ:

Kirlilik, aşırı avlanma, istilacı türler, iklim değişikliği gibi birçok çevre problemi etkisi altında kalan su ortamlarında trofik şartların değişmesi ile zararlı fitoplankton türleri çoğalarak baskın hale gelmektedir. Bu zararlı fitoplankton türlerinin aşırı çoğalması genellikle zararlı alg büyümesi ya da alg patlaması olarak adlandırılmakta ve bunun bir sonucu olarak; oluşan çok sayıdaki canlı hücreden yüksek miktarda hücre dışı polimerik organik bir madde salgılanmaktadır. Müsilaj olarak adlandırılan bu hücre dışı organik maddeler; çoğunlukla diatomlar ve dinoflagellatlar tarafindan üretilmektedir. $\mathrm{Bu}$ makale fitoplanktonların tanımlanması; fitoplanktonların meydana getirdiği ötrofikasyon ve Marmara Denizi’nde meydana gelen müsilaj probleminin anlaşılması için temel bir bilgi sunmaktadır.

ANAHTAR KELIMELER: Fitoplankton, Zararlı alg, Ötrofikasyon, Müsilaj. 
${ }^{1}$ Atatürk Üniversitesi, Mühendislik Fakültesi, Çevre Mühendisliği Bölümü, 25240 ERZURUM, E-posta: zeren@atauni.edu.tr ORCID: 0000-0003-1633-2547

\section{GÍRIŞ:}

İlk kez 1887 yılında Victor Hensen tarafindan kullanılan Fitoplankton terimi deniz biyolojisi alanında bir devrim yaratmış ve fitoplanktonların denizel besin zincirinin temelini oluşturduğu ortaya koyulmuştur (Smetacek, 1999). Aslında plankton kelimesi Yunanca "sürüklenen" anlamına gelen planktos kelimesinden türemiş ve kendi başına yüzmeyen veya mercan gibi tek bir yerde kalmayan; asılı halde kalarak gelgitlerin, akıntıların ve diğer faktörlerin etkisiyle hareket eden su ortamındaki en küçük canlı birimini temsil etmektedir. Aynı zamanda siyanobakteriler gibi bazı türleri yaşayan en eski yaşam formları olarak bilinmektedir. Planktonlar, küçük kabuklu deniz hayvanlarından balinalara kadar çok çeşitli türlere besin sağlayan tatlı su ve deniz ekosistemlerindeki besin piramitlerinin temelini oluştururlar (Bozkurt, 2019; Anonim 2019). Planktonlar biyolojik olarak, bitkisel (fitoplankton) ve hayvansal (zooplankton) plankton olmak üzere iki şekilde sınıflandırılırlar. Fitoplanktonlar, tıpkı karasal ekosistemlerdeki bitkiler gibi, fotosentez yoluyla zooplanktonlar da dahil tüm sucul canlılar için besin ve oksijen sağlayan birincil üreticilerdir. Fitoplanktonlar hücrelerinde klorofil bulunan basit yapıya sahip, tek veya çok hücreli olabilen, çoğunluğu mikroskobik büyüklükte bitkisel işleve sahip organizmalardır. Fitoplanktonlar birincil üretim için bir karbon kaynağına (su ortamında bu karbon kaynağı atmosferden suya transfer olarak suda çözünmüş hale gelen karbondioksittir), 1şık ve ortamda çözünmüş halde bulunan azot, fosfor ve kükürt gibi diğer besleyici elementlere ihtiyaç duyarlar. Fitoplanktonlar, okyanuslardaki fotosentezin \%95'inden fazlasını gerçekleştiren ve böylelikle net küresel birincil üretimin yarısını meydana getiren ototrofik (kendi besinini kendisi üreten) canlılardır. Buna karşılık okyanuslardaki bitki kütlesi biyosferdeki toplam bitki kütlesinin sadece \%0.2'sidir. Biyokütle oranına göre meydana gelen bu büyük birincil üretimin nedeni fitoplanktonların karbon dönüşüm etkinliğinin fazla olmasından kaynaklanmaktadır. Küresel fitoplankton kütlesi 2-6 günde bir yenilenirken, karasal bitkilerin kütlesi ise her 10-100 y1lda bir yenilenmektedir. Bunun sonucu olarak da fitoplanktonlar küresel oksijenin yarısını üretmektedir. Fitoplanktonların en yaygın türleri; silika kaplı bitki benzeri diatomlar, Red-Tide olarak da bilinen ötrofikasyonun açık deniz tezahürünü oluşturan dinoflagellat türleri, okyanusun kalsit üreticileri olan Coccolithophores türleri, yeşil algler ve ayrı bir sınıf olarak da Cyanobakteriler'dir (Şekil 1). Fitoplankton türleri 0.2-2 $\mu \mathrm{m}$ arasında olan bakteriyel boyuttan, 20-200 $\mathrm{cm}$ arasında gözle görülebilir mega boyutlara kadar ulaşan büyüklüğe sahip olabilmektedir (Eker-Develi, 2009; Altındağ, 2018; Anonim, 2021a).

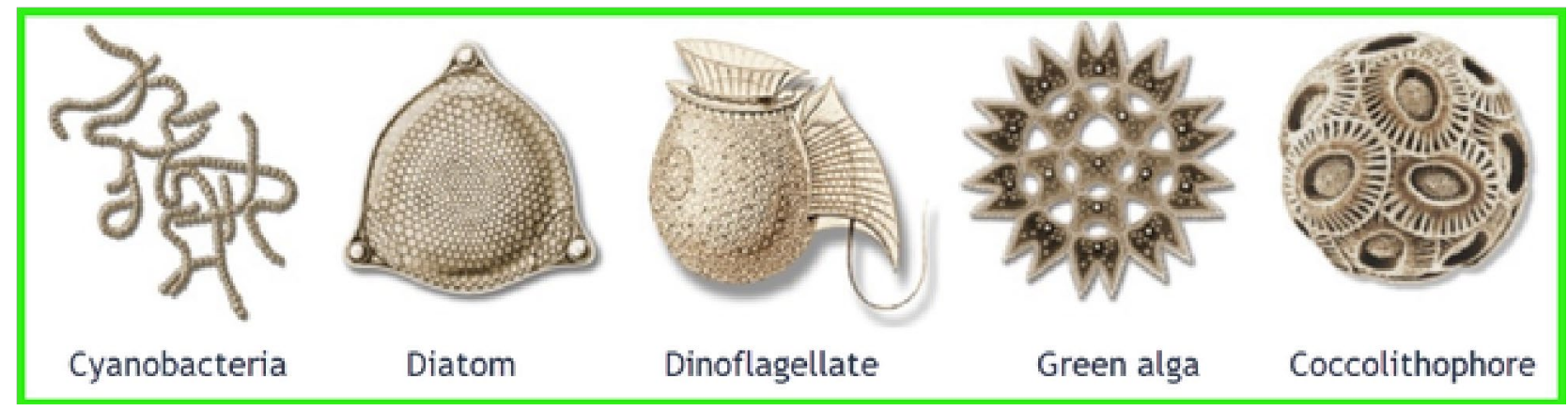

Şekil 1. Fotosentez yapan siyanobakterilerden bitkiye benzer diatomlara ve kabuklu coccolithophores'a kadar çizim ölçeğinde çeşitli fitoplankton türleri (NASA, 2010).

Fitoplanktonlar iklim değişikliği açısından da hayati önem taşımaktadır. Antropojenik karbondioksit emisyonlarının yaklaşık \%25'i karasal bitkiler tarafından bağlanırken; \%25'i de sucul üretim için küresel okyanuslar tarafindan fitoplanktonlar yolu ile bağlanmaktadır. Atmosferden yılda $10 \mathrm{Gt}$ karbon okyanuslara aktarılmaktadır. Bu nedenle fitoplankton büyümesindeki küçük değişiklikler bile küresel yüzey sıcaklıklarını geri besleyecek olan atmosferik karbondioksit konsantrasyonlarını etkileyebilmektedir. Diğer taraftan sanayi devriminden günümüze kadar insanlar tarafından atmosfere verilen toplam karbondioksit emisyonlarının \% 40 ' $1 n$ absorbe ettiği tahmin edilen okyanusların bu nedenle asitleşme sorunu ile karşı karşıya kaldığı ve bu sorunun yüzeye yakın açık okyanusun \%95'inden fazlasını etkilediği öngörülmektedir. Okyanusların öngörülebilir küresel karbondioksit emisyonlarının \%70-80'ini absorbe edebilecek kapasiteye sahip olduğu da belirtilmektedir (6). 
Mikroalgler ya da tek hücreli algler olarak da bilinen fitoplanktonlar, prokaryotik algler (Mavi-yeşil algler, Cyanophyta) olup klorofil içermeleri ve yaşamsal aktiviteleri için güneş ışığına ihtiyaç duymaları bakımından karasal bitkilerle benzer özellikler taşımaktadır. Güneş ışığ bağlayarak oksijen üretirler. Alglerin diğer sınıfı olan makroalgler ise ökaryotik algler olup; birkaç metre boya kadar değişik morfolojilerde bulunabilen ancak bitkilerde olduğu gibi kök, gövde ve yaprak benzeri yapılara sahip olmayan ve genellikle sucul ortamda çok geniş bir yayılıma sahip primer üretici canlılardır. Alglerin klorofilden başka karoten ve fikobilinler olmak üzere iki farklı pigment grubuna daha sahip oldukları görülmektedir. Klorofil-a bütün alg gruplarında bulunurken; Klorofil-b yeşil alglerde (Chlorophyta), Klorofil-c kahverengi alglerde (Phaeophyta) ve Klorofil-d ise kırmızı alglerde (Rhodophyta) mevcuttur. Karoten çeşitli alg gruplarında, karoten türevi ksantofil ise Chromophycophyta'da; mavi renkli fikosiyanin ve kırmızı renkli fikoeritrin ise cyanophyceae ve rhodophyceae türlerinde mevcuttur. Klorofilden başka diğer pigmentlerin fazla olması halinde yeşil renk baskılanarak, karoten ve ksantofil fazlalığında kahverengi; fikobilin fazlalığında ise morumsu veya kırmızı renkte görünürler. Suda görülen renk fitoplanktonun türüne, klorofilin derecesine ve pigmentlerin varlığına göre değişiklik gösterebilmektedir. Dolayısı ile yeşil ve kahverengi renkli suların berrak sulara göre daha fazla plankton içerdiğini söylemek yanlış olmaz. Fitoplankton ya da mikroalglerin büyümesi de kara bitkileri gibi karbondioksit, güneş ışı̆̆ ve diğer besin maddelerinin mevcudiyetine bağlıdır. Fitoplanktonlar, türlerine bağlı olarak karbon, azot, fosfor, kükürt, potasyum, magnezyum ve kalsiyum gibi temel besin maddeleri ile; demir, mangan, silisyum, çinko, bakır, kobalt, molibden gibi ikincil iz elementlere ihtiyaç duyarlar. Örneğin; bazı fitoplanktonlar sınırlayıcı element olan demir konsantrasyonunun çok az olduğu okyanusun geniş alanlarında büyümek için eser miktarda demire ihtiyaç duymaktadır. Karbon dışındaki major besin maddeleri ise genellikle su ortamındaki mikroorganizmaların organik maddeyi parçalaması esnasında açı̆̆a çıkan nitrat, fosfat ve sülfat bileşiklerinden elde edilir. Bu bileşikler doğal su ortamında sınırlıdır ve dolayısı ile fitoplankton büyümesini kontrol altında tutulur. Siyanobakteriler fitoplanktonlar içerisinde spesifik olarak atmosferik azotu bağlama kapasitesine sahiptir. Ancak, tarımsal, endüstriyel faaliyetler ve yeterince arıtılmamış kentsel atıksular vasıtası ile su ortamına özellikle nitrat ve azot bileşiklerinin kontrolsüz bir şekilde deşarj edilmesi bu bileşiklerin konsantrasyonlarını artırır. Artan azot ve fosfor yükü ile büyüme için gerekli diğer tüm koşullar (1s1, 1şık, iz elementler vb.) uygun olduğunda, fitoplankton popülasyonları, ani ve çok hızlı bir şekilde artmaya başlar. Çiçeklenme (bloom) olarak da bilinen bir fenomen olan bu büyüme (alg patlaması olarak dilimizde yaygınlaşmıştır), mikro boyuttaki fitoplanktonların aşırı büyüme ile bir araya gelerek büyük su kütlelerinde yüzlerce kilometrekareyi kaplayabilen ve çılak göz ile ya da uydu görüntülerinde bile rahatlıkla görülebilen koloniler halindeki bir büyümeyi ifade etmektedir. $\mathrm{Bu}$ ani ve hızlı büyüme sınırlayıcı besin maddelerinin doğal su ortamında bulunduğu hali ile gerçekleştiğinde genellikle çiçeklenme olarak ifade edilmesine rağmen; sınırlayıcı besin elementlerinin insan eliyle verildiği (kirletildiği) sucul ortamlarda meydana geldiğinde ise genellikle "alg patlaması" veya "ötrofikasyon" olarak ifade edilmektedir. Bu insan eliyle meydana gelen kirlenme sonucu oluşan alg patlaması olayı haftalarca sürebilir, ancak herhangi bir fitoplankton türünün ömrü genellikle birkaç günden fazla olmamaktadır (Aktar ve Cebe, 2010; NASA 2010; Anonim 2020a). Bu çalışmada insan eliyle meydana gelen kirlenmeler sonucu gerçekleşen büyümeyi kapsadığı için devam eden kısımlarda "zararlı alg patlaması" olarak ifade edilecektir.

Aslında göl, gölet ve rezervuar gibi durgun su ortamlarının zamanla tortul organik bileşiklerle dolması sonucu besin maddeleri ile zenginleşerek milyonlarca yıla varabilen doğal bir yaşlanma sürecine girmeleri ötrofikasyon olarak adlandırılmaktadır. Bu durgun su ortamlarındaki besin maddelerince zenginleşme sediment birikintisi, yağışlar ve bitki ve hayvan artıkları ile meydana gelir ve zamanla yüksek düzeyde biyolojik üretkenliğe sahip olurlar. Zengin besin içeriği, özellikle azot ve fosfor gibi bileşenler bu tür göllerin bol miktarda bitkisel üretimi desteklemesine neden olur. $\mathrm{Bu}$ süreç doğal ötrofikasyondur. Doğal ötrofikasyonun dışında, insan faaliyetleri ile giderek artan bir şekilde sucul ortamların ve toprağın hızla kirlenmesi, su kalitesinde ve sucul ekosistem bileşenlerinde insan eliyle gerçekleşen bir ötrofikasyon süreci meydana getirmektedir. Bu durum göllerin ya da durgun su ortamlarının erken yaşlanmasına ve zaman içerisinde canlılık özelliğini kaybederek ölmesine yani kurumasına neden olmaktadır. Bu nedenle, yoğun endüstri ve tarım faaliyetlerinin su kalitesinde ve sucul ortamın biyolojik özelliklerinde bu tür değişikliklere neden olduğunun fark edilmesiyle birlikte 1940'lardan itibaren "ötrofikasyon" terimi insan eliyle bozulan durgun su ortamları için yaygın olarak kullanılmaya başlanmıştır. 1980'lerin sonlarından itibaren de göller gibi durgun veya çok yavaş karışım gösteren sucul ortamlarda yaygın olarak toksik mavi-yeşil bakteri büyümeleri tüm dünyada tatlı su ekosistemlerinin en büyük sorunu haline gelmiştir. Siyanobakteriler olarak da bilinen bu mavi-yeşil bakteriler yalnızca fotosentetik oldukları için değil, aynı zamanda bazıları çok hücreli olabildikleri ve uzun hücre zincirleri oluşturabildikleri için tipik bakteriler sınıfında yer almazlar. Bununla birlikte, hücre içi yapıları bakteriyel sınıfa ait olduklarını göstermektedir ve fotosentez yapan bakteriler olarak da adlandırılmaktadır. Siyanobakteriler ve mikro algler ortak fotosentez yeteneğine sahip olup farklı fiziksel özellik taşıyan fitoplanktonlardır. Sınıflarından bağımsız olarak tüm fitoplanktonlar en az bir tür klorofil 
içerir ve bu böylelikle enerji üretmek için fotosentez yapabilirler. İnsan eliyle meydana gelen bu ötrofikasyon sürecinde siyanobakterilerden başka çoğunlukla dinoflagellatlar, diatomlar, rafidofitler ve prymnesiophytes gibi zararlı fitoplankton türleri de baskın olmaktadır. Bu nedenle insan eliyle gerçekleşen ötrofikasyon prosesi son yıllarda literatürde yaygınlaşmış kullanımı ile "zararlı alg patlaması-harmful algal bloom (HAB)" olarak adlandırılmaktadır. Zararlı alg patlamasına neden olan en yaygın toksik fitoplanktonlar olan dinoflagellatlar çoğunlukla kıyı şeridi, körfez ve yavaş akıntıya sahip olan tuzlu deniz veya okyanus su ortamlarında baskın olurken; mavi-yeşil algler (siyanobakteriler) çoğunlukla tatlı su ortamlarında ötrofikasyonu meydana getiren baskın türler olarak bilinirler. Ancak son yıllarda özellikle deniz veya okyanus kıyı şeridindeki su ortamlarında diatom konsantrasyonları da gittikçe artan bir endişe uyandırmaktadır. Sağlıklı sucul ekosistemler için besin zinciri büyük ölçüde fitoplanktonlara bağlı olduğundan, fitoplankton popülasyonları hem su canlıları hem de insan yaşamı için büyük bir önem arz etmekte ama bir bölgede aşırı fitoplankton büyümesi ve popülasyonlarının ani artışı tüm dünyada oldukça önemli bir çevre sorunu meydana getirmektedir. Ötrofikasyon bugün küresel ölçekte karşlaştığımız en önemli tatlı su sorunlarından birisidir. Bunun temel sebebi ise insan eliyle meydana getirilen kirlenmedir. Bu kirlenme içerisinde tarımsal faaliyetler büyük yer tutmaktadır, çünkü alg büyümesi için gerekli iki temel besin maddesi olan azot ve fosfor çoğunlukla tarımda kullanılan gübreler ile yüzey su ortamlarına ulaşarak aşırı bir baskı oluşturmaktadır. Son yıllarda insan eliyle meydana getirilen kirlenmeye ek olarak iklim değişikliğinin su ortamlarında sebep olduğu sıcaklık artışı da zararlı alg patlamasının bir diğer nedeni olarak gösterilmektedir. İklim değişikliği bağlamında, dünyanın birçok bölgesinde zararlı alg patlamalarının sıklı̆̆ında ve yoğunluğunda bir artış beklenmekte ve özellikle gıda güvenliği ve ekonomik sürdürülebilirlik için su ürünleri yetiştiriciliği alanlarında büyük bir endişe meydana getirmektedir (IOCCG, 2021; Anonim, 2015; Fondriest Environmental, 2014).

Hükümetlerarası İklim Değiş̧ikliği Paneli (IPCC) Dördüncü Değerlendirme Raporunda 1971-2010 yılları arasındaki deniz yüzeyi sıcaklığının her on yılda ortalama 0.11 santigrat derece ısındığını ve isınmaya devam ettiğini belirtmiş̧ir (IPCC, 2007). 2013'te yayınladıkları Beşinci Değerlendirme Raporunda ise; okyanusların 1970'lerden beri \%93 daha fazla ısı absorbladığını belirtmişlerdir. Ne yazık ki daha sıcak su ortamları fitoplanktonların daha hızlı büyümesine ve toksik türlerin daha baskın hale gelmesine sebep olmaktadır. Örneğin; Karenia brevis gibi toksik suşların ısınan su ortamlarında zararsız fitoplankton suşlarına göre daha hızlı büyüdüğü görülmüştür. Zararlı alg patlamasının son yıllarda sıkça görüldüğü Florida kıyılarında ise Florida Üniversitesi tarafından yapılan araştırmalarda isınan okyanus sularının daha zararlı alg türlerinin büyümesine neden olacağı belirtilmiştir (Anonim, 2015). İklim değişikliğinin zararlı alg büyümesi üzerindeki bir diğer önemli etkisi ise; geçmişte mevsimsel olarak yaşanan ve sonra kaybolan bu büyümelerin, su ortamının sicaklıklarının yükselmeye devam etmesi ve sicak kalmaya devam etmesi durumunda zararlı alg büyümelerinin yıl boyunca sürebileceği şeklindedir. Artan sıcaklıkların büyüme hızını, pigment içeriğini, enzim reaksiyonlarını ve fotosentezi etkilediği bilinmektedir. Örneğin birçok diatoma türünde özellikle nitratın alımı ve indirgenmesinin sıcaklıkla azaldığı da tespit edilmiş̧tir (Anonim, 2020b; Glibert, 2016). Şekil 2'de Florida kıyılarında görülen ve Red Tide olarak adlandırılan zararlı alg patlamasının uydu fotoğrafı yer almaktadır. 


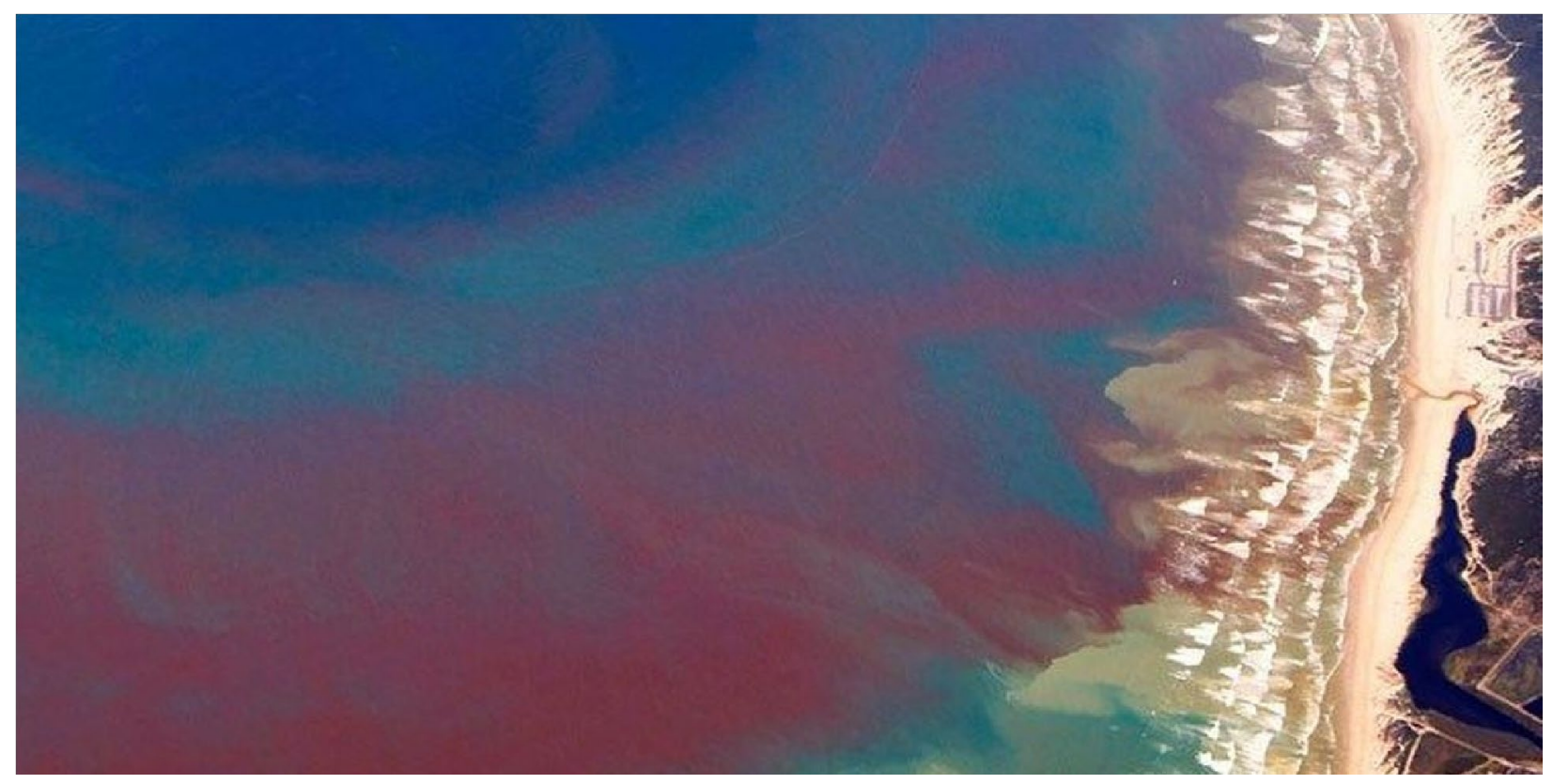

Şekil 2. Florida kıyılarında görülen ve Karenia brevis, Dinophysis, Gonyaulax, Alexandrium, Gambierdiscus toxicus türü fitoplanktonların sebep olduğu Red Tide (Anonim 2020b).

Red Tide doğal olarak meydana gelmekle beraber, son yıllarda artan kıyı bölgesi kirlenmesinin ve 1sınan suların bu büyümeyi artırarak daha uzun süre dayanmalarını ve daha geniş alanları kapsadığını gösteren çok sayıda çalışma yapılmıştır. Red Tide'ın, mavi-yeşil alg büyümesine benzer olduğu ancak mavi-yeşil alg büyümesinden farklı olarak deniz/tuzlu su kütlelerinde meydana geldiği belirtilmiştir. Tuzlu su ortamlarında siyanobakteriler ve diğer algler de bulunabilmesine rağmen, deniz fitoplanktonları esas olarak dinoflagellatlar ve diatomlar olarak bilinen mikroalglerden meydana gelmektedir. Mavi-yeşil alg (siyanobakteriler) büyümeleri esas olarak tatlı su kütlelerinde meydana gelmektedir. Dengeli bir sucul ekosistemde doğal fitoplankton konsantrasyonu; bir litre okyanus suyunda yaklaşı 1.000 hücre veya daha az olarak belirlenirken; bir Red Tide olayı esnasında bu miktarın bir litre okyanus suyunda yaklaşık 1 milyon hücreye hatta 20 milyon hücreye kadar ulaştı̆̆ını gösteren bir "patlama" meydana gelmektedir ve buna yerel fitoplanktonlar sebep olmaktadır (Anonim, 2020b). Şekil 3'te ise 2011 yllında Kuzey Amerika'da Erie Gölü'nde meydana gelen ve siyanobakterilerin sebep olduğu mavi-yeşil alg patlaması görülmektedir. Klorofil-a'ya ek olarak, mavi-yeşil algler bakterilere mavimsi renklerini veren fikoeritrin ve fikosiyanin pigmentlerini de içermektedirler. 


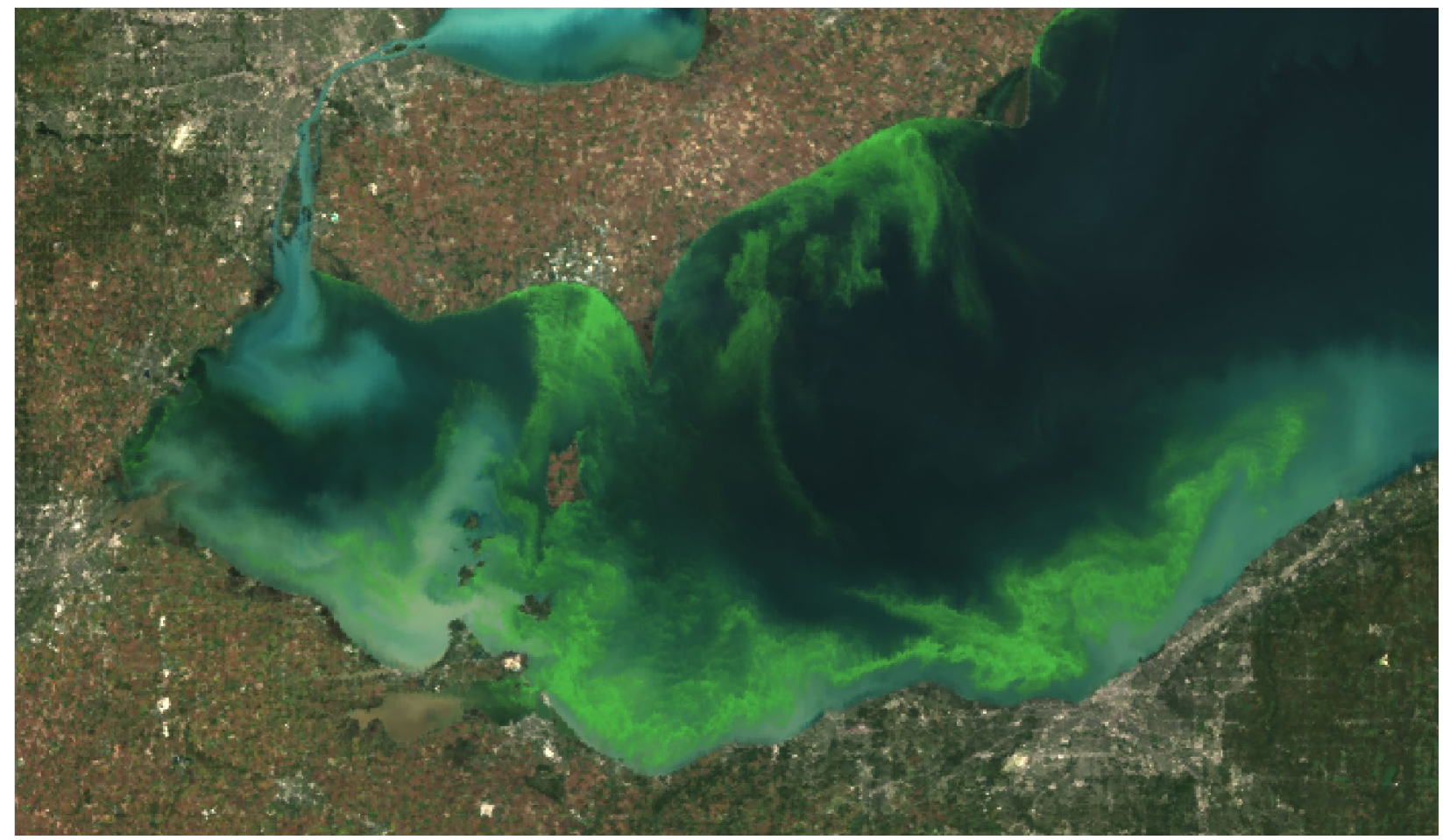

Şekil 3. Erie Gölü’nde meydana gelen ve siyanobakterilerin sebep olduğu mavi-yeşil alg patlaması, MERIS/NASA (Fondriest Environmental, 2014).

Zararlı alg patlamaları farklı fitoplankton sınıfları tarafından meydana geldiği için kızıl, mavi-yeşil dahil olmak üzere sarı, kahverengi ve su yüzeyinde bir köpük tabakası şeklinde de görülebilmektedirler. Bu mukus benzeri köpük tabakasının en önemli örneği ise; son günlerde Marmara Denizi'nde meydana gelen müsilaj olarak ifade edilen zararlı alg patlamasidır.

\section{Zararlı Alg Büyümesinin Genel Etkileri}

Zararlı alg patlamalarının neden olduğu zararlı etkiler iki yönlüdür. Birincisi; bu alg topluluklarının kendisi organizmalar için zehirli toksinler içermekte ve sucul canlılar için birbirini izleyen beslenme seviyelerinde artma eğilimi göstererek besin zincirinde biriken bu toksinlerden etkilenmektedir. Bu organizmalar içerisinde dinoflagellatlar ve diatomlar öncelikle kabuklu deniz ürünlerinin zehirlenmesine neden olmaktadır. Göllerde, nehirlerde, haliçlerde ve kıyı denizlerinde sıklıkla meydana gelen bu problem içme suyunun kontaminasyonu, daha yüksek trofik seviyeli organizmalardaki (kara hayvanları vb.) toksinlerin konsantrasyonu ve etkilenen su kütlelerinin rekreasyonel, ekonomik ve ekolojik değerinin kaybolmasına neden olmaktadır. İkincil zararlı etkisi ise fitoplankton büyümesinin çok yoğun olması nedeniyle aşırı biyokütle artışı sonucu balıkların ve omurgasızların solungaçlarının tıkanması ve anoksik (oksijensiz) ortamların meydana gelmesi ile oksijene bağlı organizmaların oksijensiz kalarak hareket kabiliyetlerinin sınırlanmasına ve hatta ölmelerine sebep olmasıdır (IOCCG, 2021). Bütün zararlı algler toksik bileşik üretmez; bazıları doğrudan su canlıları için toksik olan bileşikler üretirken bazıları da aşırı büyüme ile meydana gelen biyokütle yoluyla zehirlenmelere neden olurlar. Oluşan bu canlı alg kütleleri zamanla ölür ve su ortamında bakteriler için oksijen tüketilen bir organik madde haline dönüşür. Dolayısı ile aşırı biyokütle üretimi su canlıları için dolaylı olarak anoksik şartların meydana gelmesine neden olur. Alg türlerinin ürettiği birçok toksik bileşik bulunmaktadır; bunların bazıları balıkları doğrudan öldürürken (Şekil 4) bazıları da kabuklu deniz canlılarında birikerek onları tüketen insanlar için sağlı̆ga zararlı etkiler meydana getirebilir. Son yıllarda Florida kıyılarında meydana gelen ve $K$. brevis türünün sebep olduğu Red Tide olayında algal toksinlerin havada partiküler hale geçtiği ve solunum sıkıntılarına sebep olduğu belirtilmiştir. Dolayısı ile bu toksinleri ve zararlı etkilerini ortaya koyabilecek daha fazla araştırmaya ihtiyaç duyulmaktadır. Algal toksinlerle ilgili en temel endişe kaynağ içme suyu kaynakları ile yapacağı muhtemel kontaminasyon yollarıdır. Özellikle zararlı siyanobakteri türlerilerinin salgıladıkları toksinlerin cilt teması ile ciltte tahrişe (döküntü veya cilt kabarcıkları), gözlerde, burunda ve boğazda ve solunum yollarında iltihaplanmaya neden olabileceği; bu toksinlerin yüksek 
konsantrasyonlarına maruz kalmış içme sularının mide bulantısı, kusma, karın ağrısı ve ishale neden olabileceği ve hatta çiftlik hayvanları ve insanların karaciğer ve sinir sistemi üzerindeki etkileri olduğu da yapılan çalışmalar ile kanıtlanmıştır (Eren, 2018). Zararlı alg patlamasının sucul ekosistem üzerinde yarattığı diğer etkiler aşırı fitoplankton büyümesinin, kolay tüketilen alg türlerinin yerini alması, böylelikle zooplanktonların beslenme dengesini bozması ve enerjinin daha yüksek trofik seviyelere transferinin azalmasına neden olmasıdır. Bu durum karbon ve diğer besin maddelerinin besin ağının üst seviyelerine aktarımının düşmesine ve balık popülasyonlarının azalmasına neden olabilmektedir. Ötrofiye ortamlardaki bu besin fazlalığı veya besinlerin stokiyometrik dengesinin dışında olması, besin açısından zengin bir habitatta bile besin dengesizliğine ve zararlı/zararlı olmayan alg türleri arasındaki rekabet ortamının değişmesine de yol açmaktadır (Mitra ve Flynn, 2006; Burkholder vd., 2008). Bu ilişkileri anlamak için, farklı alg fonksiyonel grupları veya zararlı alg patlaması sınıflarının ilişkilerini inceleyen birçok kavramsal model geliştirilmiştir. Son yıllarda insan ve çevre sağlığı sorunlarına ek olarak, zararlı alg patlamalarının turizm ve ekonomik etkileri de sıkça gündeme gelmektedir (Flynn vd., 2013; Flynn vd., 2015; Anonim 2015).

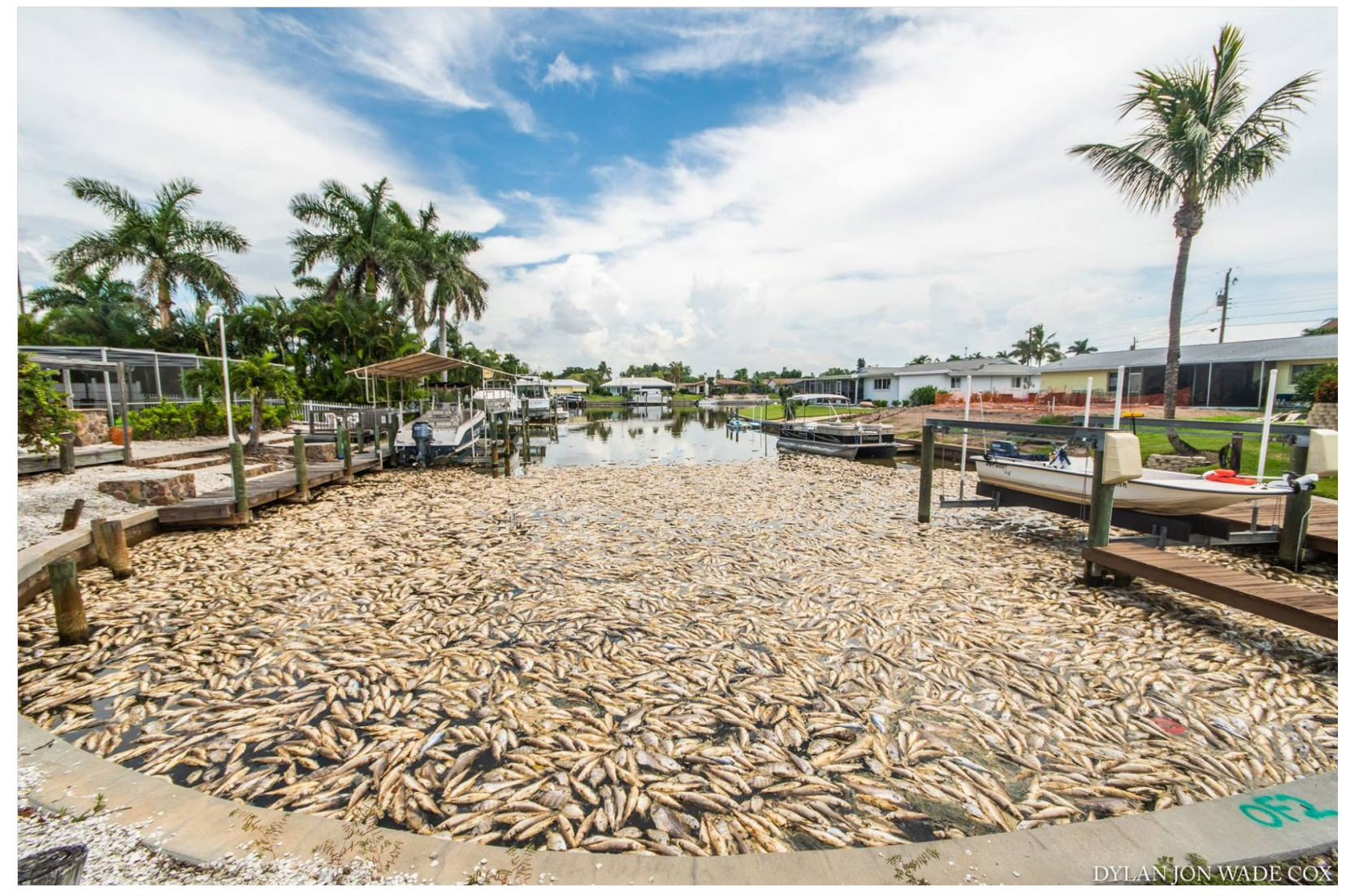

Şekil 4. 2017-2018 yılları arasında Florida kıyılarında meydana gelen Red Tide olayında 2000 tona yakın su canlısı ölümü tespit edilmiştir (Burkholder vd., 2008).

\section{Marmara Denizi ve Müsilaj Olayı}

2021 yılının ilk aylarından itibaren ulusal gündemimizde yer almaya başlayan (Anonim, 2021c) Marmara Denizi'nde meydana gelen zararlı alg patlaması veya kamuoyundaki yaygın adıyla müsilaj olayı aslında 2000'li yıllardan itibaren pek çok araştırmanın odağı olmuştur. Türkiye'nin ilk yeryüzü uydu istasyonu İTÜ CSCRS tarafından Mart ayı itibari ile uzaydan alınmaya başlanan uydu görüntülerinde Marmara Denizi'ndeki müsilaj artış oranı açıkça görülmektedir. Kapıdağ Yarımadası'ndan İzmit Körfezi'ne kadar olan Marmara Denizi'nin doğu kesiminde müsilajın 14 Mayıs'ta 25 kilometrekare, 19 Mayıs'ta 58 kilometrekare, 24 Mayıs'ta 85 kilometrekarelik bir alana ulaştığı belirtilmiştir (Şekil 5). Yüksek çözünürlüklü uydu görüntülerinde, müsilajın zaman zaman Marmara Denizi’nin tamamına yayıldığı tespit edilmiştir (İTÜ, 2021). Şekil 6'da ise müsilajın deniz dibindeki yayılımı yer almaktadır. Deniz tabanında meydana gelen bu şeffaf, sümüksü ve metrelerce uzayan tabaka başta su canlılarının yaşamsal faaliyetlerini etkilerken, özellikle balıkçılık endüstrisi üzerinde de olumsuz sonuçlar doğurduğu belirtilmiştir (Anonim, 2021d). 2021 yllında gerçekleşen 
müsilaj oluşumundan önceki son müsilaj olayı Aralık 2020'de Çanakkale Boğazı'nda kaydedilmiştir (SavunHekimoğlu ve Gazioğlu, 2021).

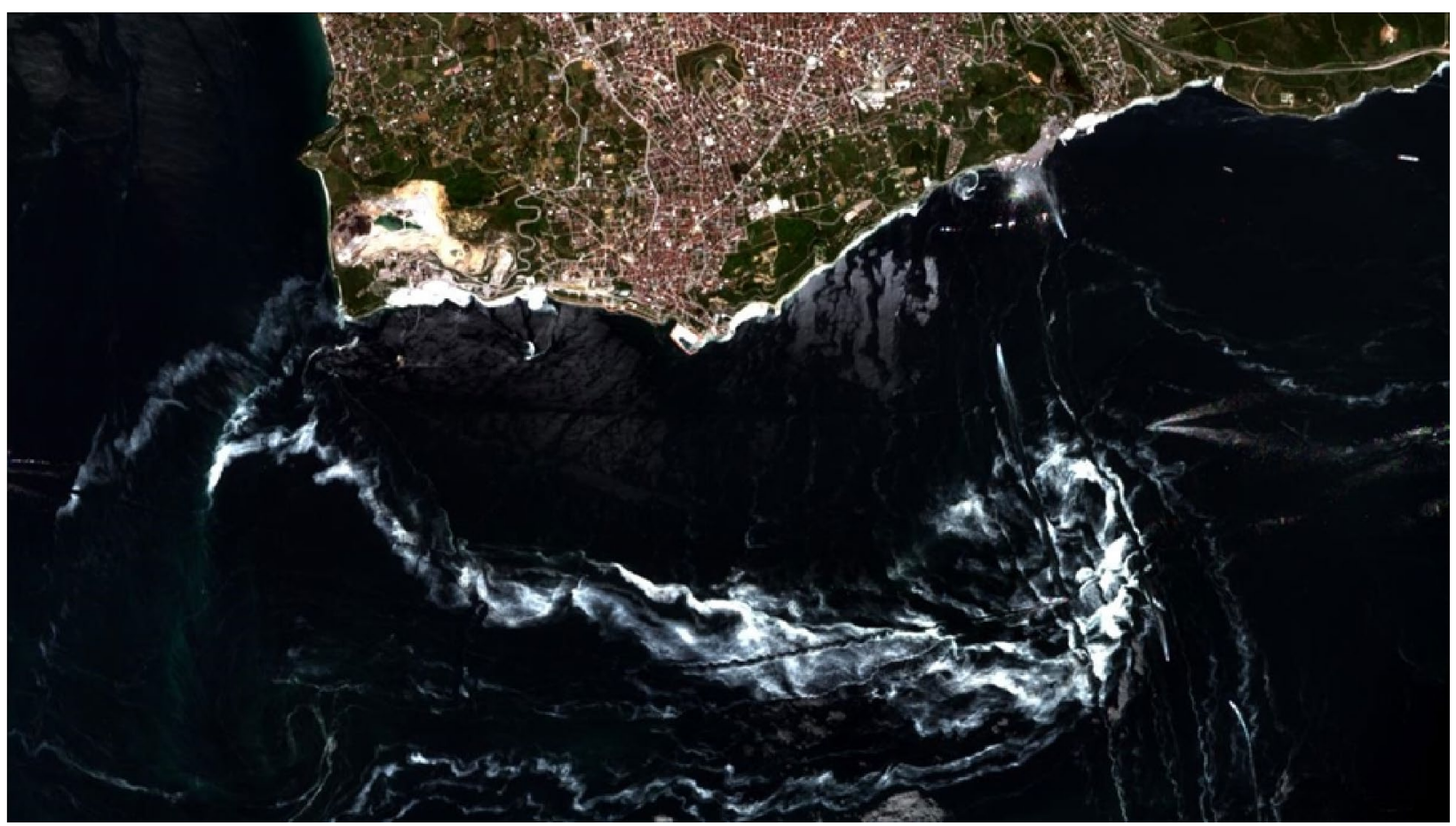

Şekil 5. Marmara Denizi’ndeki müsilajın uydu görüntüleri, 11.06.2021

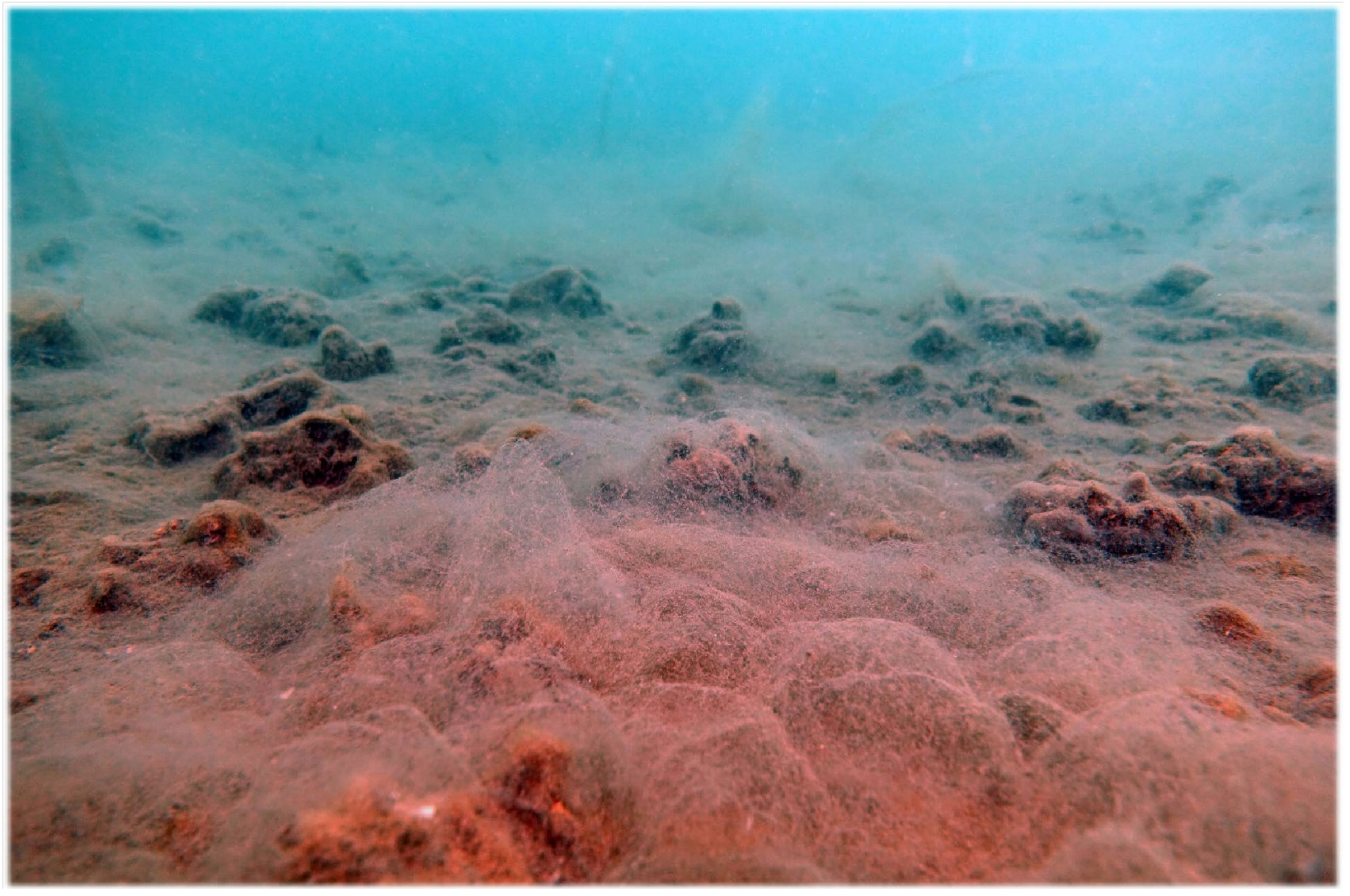

Şekil 6. Marmara Denizi’ndeki müsilajın deniz dibinden çekilen görüntüleri, 30.05.2021. 
Mayıs 2008'de yapılan ve UNESCO Hükümetlerarası Oşinografi Komisyonu (The Intergovernmental Oceanographic Commission of UNESCO) tarafından yayınlanan bir çalışmada; 2007 yılı sonbaharında Marmara Denizi'nin kuzeydoğu kesimi boyunca $18.4 \pm 1.0{ }^{\circ} \mathrm{C}$ sıcaklıkla birlikte ilk müsilaj gözlendiği belirtilmektedir. Sakin havalarda İzmit Körfezi'nden Çanakkale Boğazı'na kadar uzanan bu müsilaj olayının yoğun sanayi faaliyetinden etkilenen ve Marmara Denizi’ne göre daha zayıf bir sirkülasyona sahip olan İzmit Körfezi’nde daha yoğun ve daha uzun süreli görüldüğü belirtilmiştir. Genel olarak tarihsel altyapıda diatomlar ve onların polisakkarit olarak bilinen hücre dışı salımı nedeniyle müsilaj problemi meydana geldiği bilinmektedir. Marmara Denizi'nde yaşanan bu müsilaj olayında da alınan numunelerde yoğun olarak diatom türü (litrede $10^{7}$ hücreden fazla) fitoplanktonlar tespit edilmiştir. Ayrıca eş zamanlı olarak dinoflagellat müsilajı (litrede $36 \times 10^{3}$ ) da meydana geldiği ve İstanbul açıklarında ise Coccolithophores türlerinde büyük bir artış gözlendiği belirtilmiştir. $\mathrm{Bu}$ çalışma esnasında müsilaj nedeniyle balık ölümleri kaydedilmediği ancak büyük miktarda müsilaj agregalarının balıkçılık ve sportif dalış faaliyetlerini etkilediği; sedimentlerde ve midyelerde de yaygın bentik müsilaj agregaları gözlendiği; bu agregaların tortu, midye ve yengeç vb. üzerinde yoğun çökelmelerinin bentik ekosistemi olumsuz etkilediği belirtilmiştir (Aktan vd., 2008). 2007 yılı sonbaharında Marmara Denizi'nde önemli ekonomik ve çevresel etkilere neden olan çok yoğun bir müsilaj oluştuğunu gösteren başka bir çalışmada ise; 2004-2007 yılları arasında kuzeydoğu Marmara Denizi'ndeki fitoplankton bileşimindeki zamansal değiş̧iklikler incelenerek; çalışma süresince potansiyel olarak toksik türlerin oluşumu ve bağlantılı olarak müsilaj olayı ortaya koyulmuştur. Potansiyel olarak toksik türler olan diatom Pseudo-nitzschia spp. ve dinoflagellat Prorocentrum micans. kıyı istasyonlarında yaygın olarak gözlenmiştir. Oluşan müsilaj kalın-kremsi yüzey birikimleri ve üst tabaka boyunca dağılmış çeşitli büyüklükteki agregalarla karakterize edilen bir tabaka olup; pelajik balıkçılığın neredeyse sona ermesi ve tür sayısı ve çeşitlilik indeksinde belirgin bir düşüş de dahil olmak üzere tür kompozisyonunda önemli değişiklik gözlenmiştir. Dolayısı ile müsilaj oluşumu baskın türlerin birey sayısındaki artışla ilişkilendirilmiştir. Çalışmada ayrıca Karadeniz'den sonra Türkiye'nin en önemli ikinci balıkçılık alanı olan Marmara Denizi'nin müsilaj oluşumuna sebep olan fitoplankton patlamalarının sayısı ve büyüklüğündeki potansiyel bir artış riskinin, halihazırda kıt olan alt tabaka çözünmüş oksijen seviyelerinin tükenmesi yoluyla sistemin havza çapında çökmesine yol açabileceği belirtilmiştir. Bu nedenle iklim değişikliğine uyum stratejisi olarak, yüzey ve alt tabakaya yapılan evsel ve endüstriyel deşarjların biyolojik olarak arıtılması gerektiği, fitoplankton tür ve konsantrasyonlarının sürekli izlenmesi ve ayrıca HAB ile ilgili olası halk sağlı̆̆ sorunlarına ilişkin erken uyarıda bulunmanın önemi vurgulanmıştır (Taş vd., 2020). Aynı dönem meydana gelen müsilaj olayını inceleyen başka bir çalışma ise yoğun fitoplankton konsantrasyonu ve bağlı olarak meydana gelen müsilajın sucul ekosistemin beslenme dengesini bozduğunu ve zooplankton bolluğunda azalmaya sebep olduğunu ve zamansal ve mekânsal değişimlerini etkilediği belirtmiş̧tir (Okyar vd., 2015). Aynı dönem Çanakkale Boğazı kıyı şeridinde bulunan Güzelyalı ve Abide istasyonlarında gerçekleştirilen bir başka araştırma sonuçlarına göre ise ani sıcaklık değişimlerinin, rüzgâr hızının ve yağışın müsilajın devamı üzerinde doğrudan etkileri olabileceği belirtilmiştir (Yentur vd., 2013). Ekim 2007-Şubat 2008 döneminde en yoğun haline ulaşan bu ilk müsilaj olayı esnasında fitoplankton türleri, bileşimi ve miktarları ile buna karşılık gelen çevresel koşulların araştırıldığı bir çalışmada ise su ortamındaki yüksek çözünmüş organik madde (DOC) içeriğine dikkat çekilmiştir. Deniz ortamındaki normal çözünmüş organik madde içeriğinden 5-10 kat daha fazla organik madde varlığı belirlenerek, bu durum normalde $\mathrm{C} / \mathrm{N} \sim 18.5$ olan müsilaj içeriğinin dondurulup kurutulmasıyla $\% 24$ seviyelerine ulaştığı deneysel çalışmalar sonucunda elde edilmiştir. Ayrıca alınan numunelerdeki N:P oranları (0.1-14.4) Redfield oranı (16) ile karşılaştırıldığında düşük olduğu ve Marmara Denizi’ndeki azot sınırlayıcı birincil üretimi desteklediği ortaya koyulmuştur (Tüfekçi vd., 2010).

\section{SONUÇ:}

Zararlı alg büyümesi hem tatlı su hem tuzlu kaynaklarında ekosistem, insan sağlığı ve ekonomi için önemli bir tehdit olarak görülmektedir. Zararlı alg büyümesinin meydana getirdiği ötrofikasyon olayını ya da müsilaj oluşumunu tamamen kontrol etmek mümkün olmamakla birlikte, antropojenik etkilerin meydana getirdiği baskı azaltılarak etkilerinin azaltılması mümkün olabilecektir. Antropojenik etkilerin azaltılması için öncelikle avlanma dönemi gibi ekosistemi koruyucu tedbirlerin daha sıkı bir şekilde uygulanması gerekmektedir. Bu durum hem biyoçeşitlilik kaybını ortadan kaldıracak hem de müsilaj nedeniyle balıkçılık sektörünün yaşadığı ekonomik problemleri azaltmaya da yardımcı olacaktır. Özellikle müsilaj oluşum dönemlerinde balıkçılık faaliyetlerinin tamamen engellenmesi ise fitoplanktonlarla beslenen balıkların deniz ortamındaki fitoplankton popülasyonunu azaltarak müsilaj oluşumunun önüne geçilmesine katkı sağlayacaktır.

Zararlı alg büyümesine sebep olan antropojenik faaliyetlerin en önemlisi ise hem tatlı su kaynaklarında hem de denizlerde giderek artan besin yükü yani evsel, tarım ve endüstriyel faaliyetlerden kaynaklanan atıksulardır. Artan nüfus 
karşısında yetersiz kalan kentsel atıksu arıtma tesisleri, sanayi atıksularının yeterince arıtılamaması, dip kısımlarda organik madde yükünü artıran derin deniz deşarjı uygulamaları ve yayılı tarım ve hayvancılık faaliyetlerinden kaynaklanan atıklar, su ortamlarındaki fitoplanktonlar için önemli miktarda azot ve fosfor kaynağı oluşmasına sebep olmaktadır. Bu nedenle azot ve fosforun etkin bir şekilde atıksulardan giderildiği ileri arıtma teknolojilerinin mevcut atıksu arıtma tesislerine entegre edilmesi büyük önem taşımaktadır. Entegre havza yönetim planları acil olarak uygulamaya koyularak tarım ve hayvancılık faaliyetlerinden kaynaklanan atıkların kontrol edilmesi hem denizlere hem durgun yüzey su ortamlarına bu atıkların taşındığı nehirlerin de kontrol altına alınması gerekmektedir.

$\mathrm{Su}$ ortamındaki bu besin maddelerine ek olarak; daha sıcak ve akıntının az olduğu durgun ortamlarda hem müsilaj oluşumu hem de ötrofikasyonun meydana gelmesi kolaylaşacağ 1 için iklim değişikliğine bağlı küresel sıcaklık artışlarının (ortalama $1.2^{\circ} \mathrm{C}$ ) durumu daha da kötüleştireceği öngörülmektedir.

Özellikle müsilaj oluşumunun; hem bazı türlerin salgıladığı zehirli toksinler hem de ortamdaki mikrobiyal aktivitenin artması gibi sebeplerle insan sağlı̆ına olası etkisinin azaltılması için, yüzme ve rekreasyon faaliyetleri gibi doğrudan temasa sebep olacak aktivitelerin engellenmesi de önerilmektedir.

\section{Etik Standart ile Uyumluluk}

Çıkar Çatışması: Yazar herhangi bir çıkar çatışması olmadığını beyan eder.

Etik Kurul İzni: Etik Kurul iznine gerek yoktur.

Finansal Destek: Yoktur.

\section{KAYNAKÇA:}

Aktan, S., Dede, A., Çiftçi-Türetken, P.S., (2008). Mucilage event associated with diatoms and dinoflagellates in Sea of Marmara, Turkey. The Intergovernmental Oceanographic Commission of UNESCO.

Aktar, S., Cebe, G. E., (2010). Alglerin Genel Özellikleri, Kullanım Alanları ve Eczacılıktaki Önemi, Ankara Ecz. Fak. Derg. 39 (3) 237-264.

Altındağ, A., (2018). Plankton Bilimi Ankara Üniversitesi, https://acikders.ankara.edu.tr Erişim Tarihi: 5.07.2021.

Anonim, (2015). Red Tides From Beachapedia, http://beachapedia.org/Red_Tides, Erişim Tarihi: 6.07.2021.

Anonim, (2020a). Algler: Protozoonlar, Ankara Üniversitesi, https://acikders.ankara.edu.tr Erişim Tarihi: 5.07.2021.

Anonim, (2020b). Scripps Institute of Oceanography \& University of California, Santa Cruz, http://beachapedia.org/Red_Tides, Erişim Tarihi: 6.07.2021.

Anonim, (2021a). Deniz Planktonu ve Ekolojisi, https://acikders.ankara.edu.tr Erişim Tarihi: 19.08.2021.

Anonim, (2021c). 5 soruda Marmara Denizi’nde deniz salyası (müsilaj) tehlikesi, https://www.ntv.com.tr/, Erişim tarihi 23.02.2021.

Anonim, (2021d) Prof. Sarı fotoğrafladı: Denizin dibi müsilaj örtüsüyle kaplanmış durumda, https://tr.sputniknews.com/cevre, Erişim Tarihi: 14.07.2021.

Anonim, (2019). Plankton: The microscopic plants and animals of the plankton family are the foundation of freshwater and seawater food pyramids. https://www.nationalgeographic.org/, Erişim Tarihi: 14.07.2021.

Bozkurt, E. (2019). Çeşitli Tatlı Su Örneklerinden İzole Edilen Bazı Mikroalglerin Antimikrobiyal Özelliklerinin ve Anti-Çoğunluk Algılama Aktivitelerinin Belirlenmesi, Kütahya Dumlupınar Üniversitesi, Fen Bilimleri Enstitüsü Biyoloji Anabilim Dalı.

Burkholder, J., P. Glibert, and H. Skelton (2008). Mixotrophy, a major mode of nutrition for harmful algal species in eutrophic waters. Harmful Algae 8: 77-93. 
Eker-Develi, E. (2009). Denizel Fitoplanktonun Ekolojik Önemi ve Küresel İklim Değişikliğindeki Rolü, Mersin Üniversitesi Eğitim Fakültesi Dergisi, Cilt 5, Sayı 2, ss. 285-293.

Eren, Z., (2018). Su Kaynaklarında İleri Oksidasyon Prosesleri (İOP) ile Ötrofikasyon Kontrolü, Ordu Univ. J. Sci. Tech., 2018; 8(2): 243-253.

Flynn, K. J. et al. (2013). Misuse of the phytoplankton-zooplankton dichotomy: the need to assign organisms as mixotrophs within plankton functional types. J. Plankton Res. 35: 3-11.

Flynn, K. J. et al. (2015). Ocean acidification with (de) eutrophication will alter future phytoplankton growth and succession. Proc. R. Soc. London B: Biol. Sci. 282:1804, 20142604.

Fondriest Environmental, Inc. (2014). Algae, Phytoplankton and Chlorophyll. Fundamentals of Environmental Measurements. https://www.fondriest.com/ Erişim Tarihi: 6.07.2021

Glibert, P. M. et al. (2016). Pluses and minuses of ammonium and nitrate uptake and assimilation by phytoplankton and implications for productivity and community composition, with emphasis on nitrogen-enriched conditions. Limnol. Oceanogr. 61:1, 165-197.

IOCCG, (2021). Observation of Harmful Algal Blooms with Ocean Colour Radiometry. Bernard, S., Kudela, R., Robertson Lain, L. and Pitcher, G.C. (eds.), IOCCG Report Series, No. 20, International Ocean Colour Coordinating Group, Dartmouth, Canada.

IPCC, (2007). Fourth Assessment Report. https://www.ipcc.ch/report/ar4/syr/, Erişim Tarihi: 19.08.2021.

IPCC, (2019). Changing Ocean, Marine Ecosystems, and Dependent Communities. In: IPCC Special Report on the Ocean and Cryosphere in a Changing Climate.

İTÜ, (2021). Mucilage in the Sea of Marmara Viewed from Space, https://web.cscrs.itu.edu.tr/, Erişim tarihi 12.07.2021.

Mitra, A. and K. Flynn (2006). Promotion of harmful algal blooms by zooplankton predatory activity. Biol. Lett. 2: $194-197$.

NASA, 2010. What are Phytoplankton? https://earthobservatory.nasa.gov/ Erişim Tarihi: 6.07.2021

Okyar, M.İ., Üstün, F., Orun, D.A., (2015). Changes in abundance and community structure of the zooplankton population during the 2008 mucilage event in the northeastern Marmara Sea, Turkish Journal of Zoology, 39: 28-38 C) TÜBİTAK.

Savun-Hekimoğlu, B., Gazioğlu, C., (2021). Mucilage Problem in the Semi-Enclosed Seas: Recent Outbreak in the Sea of Marmara. International Journal of Environment and Geoinformatics 8(4): 402-413.

Smetacek, V. (1999). Revolution in the ocean. Nature 401, 647 (1999).

Taş, S., Kuş, D., Yılmaz, I. N., (2020). Temporal variations in phytoplankton composition in the north-eastern Sea of Marmara: potentially toxic species and mucilage event, Medit. Mar. Sci., 21/3 2020, 668-683.

Tüfekçi, V., et al., (2010). Phytoplankton composition and environmental conditions of a mucilage event in the Sea of Marmara, Turk J Biol 34, 199-210 C TÜBİTAK doi:10.3906/biy-0812-1

Yentur, R.E., Buyukates, Y., Ozen, O., Altin, A., (2013). The environmental and socio-economical effects of a biologic problem: Mucilage, Mar. Sci. Tech. Bull. 2(2):13-15. 